\title{
Pengaruh Edible Coating Jenis Pati Terhadap Mutu Buah Tomat Selama Penyimpanan
}

\section{Effects of Starch Type-Based Edible Coatings on the Quality of Tomato Fruit During Storage}

\author{
Gilian Tetelepta, Priscillia Picauly*, Febby J. Polnaya, Rachel Breemer, Gelora H. Augustyn \\ Jurusan Teknologi Hasil Pertanian Fakultas Pertanian Universitas Pattimura, Jln. Ir. M. Putuhena, Kampus \\ Poka Ambon 97233 \\ *Penulis Korespondensi: E-mail: priscilia_pic@yahoo.com
}

\begin{abstract}
This research was aimed to assess the effects of starch type as edible coatings on tomato fruit during storage. A completely randomized experimental design with two factor of treatment. i.e, starch type (no coating, tuni sago starch, cassava starch, and Fe'i banana starch) and storage time (5, 10, and 15 days). Variables observed including hardness, weight loss, vitamin C, total acidity and lycopene content. Results showed that stored for 15 days without coating resulted in significant decrease in hardness, vitamin C content, total acidity, and increase in weight loss and lycopene content. Whereas tomato fruits coated with tuni sago, cassava and tongka langit banana starches was found to be more effective in maintaining the quality of the tomatoes during storage.
\end{abstract}

Keywords: cassava starch, edible coating, Fe'i banana starch, tuni sago starch, tomato

\begin{abstract}
ABSTRAK
Penelitian ini bertujuan untuk mengetahui pengaruh jenis pati untuk edible coating buah tomat selama penyimpanan. Rancangan yang digunakan dalam penelitian ini adalah rancangan acak lengkap faktorial, terdiri dari dua faktor yaitu jenis pati (tanpa coating, pati sagu tuni, pati ubi kayu, pati pisang tongka langit) dan lama penyimpanan $(5,10$, dan 15 hari). Variabel yang diamati adalah kekerasan, susut bobot, vitamin C, total asam dan likopen. Hasil penelitian menunjukkan bahwa buah tomat yang disimpan hingga hari ke-15 tanpa coating secara signifikan mengalami penurunan kekerasan, vitamin $\mathrm{C}$, total asam dan mengalami kenaikan susut bobot dan likopen. Sedangkan buah tomat yang di-coating dengan pati sagu tuni, ubi kayu, pisang tongka langit efektif dalam mempertahankan mutu tomat selama penyimpanan.
\end{abstract}

Kata kunci: edible coating, pati sagu tuni, pati ubi kayu, pati pisang tongka langit, tomat

\section{PENDAHULUAN}

Tomat (Solanum lypersicum) merupakan komoditi hortikultura yang rentan terhadap kerusakan, hal ini disebabkan oleh proses fisiologis respirasi dan transpirasi yang terus berlanjut meskipun buah telah dipanen atau disimpan. Selama proses tersebut berlangsung akan terjadi proses-proses kemunduran (deteriorasi) yang mengakibatkan buah cepat rusak. Oleh sebab itu faktor-faktor yang berperan dalam memperbaiki kualitas dan daya simpan buah tomat perlu diperhatikan (Normasari et al., 2002).
Tomat termasuk jenis tanaman yang memiliki manfaat kesehatan antara lain mengurangi kolesterol darah dan trigliserida serum serta kaya akan kandungan gizi seperti vitamin A, $\mathrm{C}$, tiamin, niasin, asam folat, kalsium, zat besi, kalium dan flavonoid. Meskipun tomat kaya akan zat gizi dan memberikan manfaat kesehatan tinggi, namun tomat sangat mudah mengalami kerusakan. Kerusakan pascapanen buah tomat akibat penanganan yang tidak tepat diperkirakan antara 20\% sampai dengan 50\% (Rudito, 2005). Teknik pengemasan dengan cara pelapisan diharapkan dapat mengatasi permasalahan pascapanen sehingga tingkat kerusakan buah tomat dapat 
dihambat. Berbagai usaha untuk memperpanjang masa simpan komoditas buahan telah dilakukan antara lain dengan pengaplikasian edible coating.

Edible coating merupakan alternatif yang berfungsi sebagai pembawa (carrier) aditif makanan, seperti agen antipencoklatan, antimikroba, pewarna, pemberi flavor, nutrisi dan bumbu (Pranoto et al., 2005). Edible coating dapat berasal dari bahan baku yang mudah diperbaharui seperti campuran lipid, polisakarida dan protein (Abdi et al., 2017). Edible coating berbahan dasar polisakarida yang paling potensial dan telah banyak diteliti adalah berbasis pati-patian karena memiliki keunggulan yaitu menurunkan aktivitas air pada permukaan bahan sehingga kerusakan oleh mikroorganisme dapat dihindari karena terlindung oleh lapisan edible film, memperbaiki struktur permukaan bahan sehingga permukaan menjadi mengkilap, mengurangi terjadinya dehidrasi sehingga susut bobot dapat dicegah, mengurangi kontak oksigen dengan bahan sehingga oksidasi atau ketengikan dapat dihambat, sifat asli produk seperti flavor tidak mengalami perubahan, serta dapat memperbaiki penampilan produk (Santoso et al., 2004).

Jenis pati-patian yang sudah digunakan untuk membuat edible film meliputi pati sagu (Polnaya et al., 2012; Polnaya et al., 2006; Wattimena et al., 2016), pati ubi kayu atau tapioka (Santoso et al., 2004), pati mangga (Nawab et al., 2017), dan pati ubi jalar (Breemer et al., 2012). Penelitian ini bertujuan untuk mengetahui pengaruh jenis pati untuk edible coating buah tomat selama penyimpanan.

\section{BAHAN DAN METODE}

\section{Bahan}

Bahan baku yang digunakan dalam penelitian ini adalah tomat mentah dengan ciri-ciri keseluruhan kulit masih berwarna hijau, yang diperoleh dari petani di Desa Telaga Kodok, Kota Ambon. Pati sagu, pati ubi kayu, dan pati pisang tongka langit adalah bahan penelitian yang sudah disiapkan sebelumnya dengan kadar air $\pm 12,5 \%$. Bahan kimia lainnya seperti CMC dan gliserol dibeli dari toko bahan kimia.

\section{Pembuatan edible coating}

Pembuatan edible coating dilakukan berdasarkan metode Septiana (2009). Pati sesuai perlakuan (pati sagu, pati ubi kayu, dan pati pisang tongka langit) dimasukan dalam akuades dengan perbandingan 1:10, kemudian dipanaskan menggunakan hot plate sambil diaduk pada suhu $55^{\circ} \mathrm{C}$ selama 20 menit. Setelah itu tambahkan gliserol kemudian naikan suhu mencapai $70^{\circ} \mathrm{C}$ dan tambahkan CMC $1 \%$ sedikit demi sedikit ke dalam larutan sambil diaduk sampai homogen. Setelah itu edible coating didinginkan pada suhu ruang.

\section{Aplikasi edible coating pada tomat}

Buah tomat dicuci pada air mengalir dan dikering-anginkan. Setelah kering, buah tomat dicoating dengan metode pencelupan. Buah tomat dicelupkan ke dalam formula edible coating sesuai perlakuan. Setelah itu dikering-anginkan dengan bantuan kipas angin. Setelah kering, sampel disimpan pada suhu kamar selama 5,10, dan 15 hari dan dianalisis terhadap kualitas tomat.

\section{Pengamatan}

Pengamatan yang dilakukan pada edible coating tomat selama penyimpanan meliputi kekerasan, susut bobot (AOAC, 1995), vitamin C (AOAC, 1995), total asam (AOAC, 1995), dan likopen (Mu'nisa, 2012).

\section{Analisis data}

Data yang diperoleh dianalisa dengan menggunakan analisis ragam dan apabila hasil analisa tersebut terdapat pengaruh yang signifikan akan dilanjutkan dengan uji Tukey $(\alpha=0,05)$ untuk menentukan perbedaan antara rataan perlakuan.

\section{HASIL DAN PEMBAHASAN}

\section{Kekerasan}

Hasil analisis ragam menunjukkan bahwa interaksi antara perlakuan jenis pati dan lama penyimpanan memberikan pengaruh yang nyata terhadap peubah kekerasan tomat. Buah tomat tanpa perlakuan coating pada lama penyimpanan hari ke-5 memiliki nilai kekerasan $19,44 \mathrm{~kg} / \mathrm{cm}^{2}$, dan mengalami penurunan yang signifikan ketika disimpan hingga hari ke $10\left(10,5 \mathrm{~kg} / \mathrm{cm}^{2}\right)$ dan hari ke $15\left(7,31 \mathrm{~kg} / \mathrm{cm}^{2}\right)$. Penurunan kekerasan ini menunjukkan bahwa tomat tanpa coating lebih cepat mengalami penurunan nilai kekerasan. 
Semakin lama buah disimpan maka permukaan buah semakin lunak. Menurut Winarno dan Wirakartakusumah (1981), selama penyimpanan terjadi perubahan sebagian protopektin yang tidak larut air menjadi larut air, sehingga menurunkan daya kohesi dinding sel yang mengikat sel satu dengan sel lainnya, akibatnya kekerasan buah menurun dan menjadi lunak. Perubahan tekstur yang terjadi pada buah yaitu dari keras menjadi lunak sebagai akibat terjadinya proses kelayuan (keriput) akibat proses respirasi dan transpirasi. Proses kelayuan ini akan diikuti oleh proses senescence.

Buah tomat yang di-coating dengan perlakuan pati sagu, pati ubi kayu dan pati pisang tongka langit menunjukkan penurunan nilai kekerasan yang kecil, hal ini menunjukkan bahwa edible coating dengan perlakuan jenis pati efektif dalam mempertahankan mutu kekerasan buah tomat hingga hari ke-15 (Tabel 1). Hal yang sama juga dikemukakan oleh Breemer et al. (2017) dan Nawab et al. (2017) dimana coating berbasis pati dapat menekan kelunakan dan kerusakan buah tomat. Kelunakan buah selama penyimpanan disebabkan karena kemunduran pada komponen dinding sel, terutama karena adanya pektin serta aktivitas poligalaturonase dan enzim lainnya. Edible coating berbahan dasar polisakarida berfungsi sebagai penghalang terhadap gas sehingga $\mathrm{CO}_{2}$ menjadi tinggi dan $\mathrm{O}_{2}$ rendah dalam buah. Adanya kontrol aktivitas enzim dapat mempertahankan kekerasan buah yang di-coating selama penyimpanan.

\section{Susut bobot}

Hasil analisis ragam menunjukkan bahwa interaksi antara perlakuan jenis pati dan lama penyimpanan memberikan pengaruh yang nyata terhadap peubah susut bobot tomat. Buah tomat tanpa perlakuan coating pada lama penyimpanan hari ke-5 memiliki nilai susut bobot 2,36\% dan mengalami peningkatan susut bobot terbesar hingga $18,71 \%$ pada hari ke-15. Hal yang sama juga ditunjukkan oleh perlakuan edible coating pati pisang tongka langit, dimana buah tomat yang disimpan pada hari ke-5 memiliki nilai susut bobot $1,49 \%$ dan mengalami peningkatan yang signifikan hingga hari ke-15 yaitu $10,67 \%$. Semakin tinggi nilai susut bobot tomat maka kehilangan bobot akan semakin tinggi sehingga bobot tomat akan berkurang.

Pada perlakuan jenis pati sagu dan pati ubi terjadi penyusutan buah tomat yang lebih kecil dibandingkan perlakuan tanpa coating, hal ini menunjukkan bahwa adanya lapisan coating berbahan dasar pati sagu dan ubi kayu berfungsi baik sebagai barrier terhadap $\mathrm{CO}_{2}, \mathrm{O}_{2}$ dan air menyebabkan respirasi dan transpirasi dapat ditekan sehingga dapat mempertahankan kualitas buah. Hasil yang sama juga diungkapkan oleh Usni et al. (2016) dan Breemer et al. (2017) dimana edible coating berbahan dasar pati dapat menghambat penyusutan bobot buah.

Tabel 1. Pengaruh edible coating beberapa jenis pati terhadap mutu buah tomat selama penyimpanan

\begin{tabular}{ccccccc}
\hline \multicolumn{2}{c}{ Perlakuan } & $\begin{array}{c}\text { Kekerasan } \\
\left(\mathbf{k g} / \mathbf{c m}^{2}\right)\end{array}$ & $\begin{array}{c}\text { Susu } \\
\text { Bobot }(\%)\end{array}$ & $\begin{array}{c}\text { Vitamin } \\
\mathbf{C}(\boldsymbol{\%})\end{array}$ & $\begin{array}{c}\text { Total } \\
\text { asam }(\%)\end{array}$ & $\begin{array}{c}\text { Likopen } \\
(\boldsymbol{\%})\end{array}$ \\
\hline Jenis pati & $\begin{array}{c}\text { Lama penyimpanan } \\
(\text { hari) }\end{array}$ & $19,44 \mathrm{i}$ & $2,36 \mathrm{i}$ & $14,08 \mathrm{e}$ & $0,81 \mathrm{a}$ & 38,27 \\
Kontrol & 5 & $10,50 \mathrm{j}$ & $4,29 \mathrm{f}$ & $12,32 \mathrm{f}$ & $0,45 \mathrm{~cd}$ & 47,46 \\
(tanpa & 10 & $7,31 \mathrm{k}$ & $18,71 \mathrm{a}$ & $8,8 \mathrm{~g}$ & $0,27 \mathrm{e}$ & 53,19 \\
coating) & 15 & $21,54 \mathrm{c}$ & $2,43 \mathrm{i}$ & $21,12 \mathrm{a}$ & $0,54 \mathrm{bc}$ & 17,37 \\
\multirow{2}{*}{ Pati sagu } & 5 & $20,39 \mathrm{~g}$ & $5,86 \mathrm{e}$ & $17,60 \mathrm{c}$ & $0,45 \mathrm{~cd}$ & 19,98 \\
tuni & 10 & $20,13 \mathrm{~h}$ & $6,53 \mathrm{~d}$ & $12,32 \mathrm{f}$ & $0,36 \mathrm{de}$ & 23,94 \\
\hline \multirow{2}{*}{ Pati ubi kayu } & 15 & $22,23 \mathrm{a}$ & $2,23 \mathrm{j}$ & $21,12 \mathrm{a}$ & $0,63 \mathrm{~b}$ & 25,46 \\
& 5 & $21,28 \mathrm{~d}$ & $2,90 \mathrm{~h}$ & $15,84 \mathrm{~d}$ & $0,45 \mathrm{~cd}$ & 27,40 \\
\multirow{2}{*}{ Pati pisang } & 10 & $21,06 \mathrm{e}$ & $4,16 \mathrm{~g}$ & $15,84 \mathrm{~d}$ & $0,45 \mathrm{~cd}$ & 34,65 \\
tongka langit & 15 & $21,77 \mathrm{~b}$ & $1,49 \mathrm{k}$ & $21,12 \mathrm{a}$ & $0,63 \mathrm{~b}$ & 35,15 \\
& 5 & $21,77 \mathrm{~b}$ & $8,82 \mathrm{c}$ & $19,36 \mathrm{~b}$ & $0,54 \mathrm{bc}$ & 39,70 \\
\hline
\end{tabular}

Keterangan: Angka yang diikuti huruf yang tidak sama menyatakan berbeda nyata pada uji BNJ $\alpha=0,05$ 


\section{Vitamin C}

Hasil analisis ragam menunjukkan bahwa interaksi antara perlakuan jenis pati dan lama penyimpanan memberikan pengaruh yang nyata terhadap peubah vitamin $\mathrm{C}$ tomat. Buah tomat yang di-coating dengan pati sagu, pati ubi kayu dan pati pisang tongka langit pada hari ke-5 memiliki kadar vitamin C paling tinggi $21,12 \%$ dibandingkan buah tomat tanpa coating 14,08\%. Hal ini menunjukkan bahwa coating dengan pati sagu, ubi kayu dan pisang tongka langit mampu mempertahankan kadar vitamin $\mathrm{C}$ karena dapat menghambat difusi $\mathrm{O}_{2}$ kedalam jaringan buah dan reaksi oksidasi penyebab kerusakan vitamin $\mathrm{C}$ dapat diperlambat.

Kandungan vitamin $\mathrm{C}$ buah tomat untuk setiap perlakuan mengalami penurunan seiring peningkatan lama penyimpanan. Hasil ini sejalan dengan penelitian Apandi (2009) bahwa semakin lama penyimpanan kadar vitamin $\mathrm{C}$ semakin menurun. Penurunan kadar vitamin $\mathrm{C}$ terbesar terlihat pada buah tomat tanpa perlakuan coating dibandingkan buah tomat yang di-coating dengan perlakuan jenis pati.

\section{Total Asam}

Hasil analisis ragam menunjukkan bahwa interaksi antara perlakuan jenis pati dan lama penyimpanan memberikan pengaruh yang nyata terhadap peubah total asam tomat. Hasil penelitian yang disajikan pada Tabel 1 menunjukkan bahwa nilai total asam pada buah tomat semakin berkurang selama penyimpanan. Buah tomat tanpa coating pada hari ke 5 menunjukkan nilai total asam tertinggi $0,81 \%$ namun mengalami penurunan yang signifikan ketika disimpan pada hari ke-15 $(0,27 \%)$. Sedangkan buah tomat yang diberi coating pati sagu, pati ubi kayu dan pati pisang tongka langit menunjukkan penurunan terkecil ketika disimpan selama 10 dan 15 hari.

Hasil yang sama ditunjukkan oleh Fitri et al. (2012) dimana buah tomat yang di-coating dengan pektin memiliki nilai total asam yang lebih tinggi dibandingkan dengan tomat tanpa coating. Hal ini disebabkan oleh proses respirasi pada buah tomat tanpa coating lebih besar sehingga asam organik akan cepat berkurang.

\section{Likopen}

Pantastico (1993) menyatakan bahwa perombakan pigmen klorofil sejalan dengan sintesis pigmen likopen sehingga warna buah menjadi kemerahan. Tinggi rendahnya kadar likopen menunjukkan indeks warna pada tomat yang berkaitan dengan tingkat kematangan, dimana semakin merah warna tomat maka semakin banyak pula kandungan likopen didalamnya. Hasil analisis ragam menunjukkan bahwa interaksi antara perlakuan jenis pati dan lama penyimpanan berpengaruh tidak nyata terhadap peubah likopen tomat. Hal ini menunjukkan bahwa perlakuan jenis pati tidak berpengaruh terhadap kadar likopen tomat selama penyimpanan hingga hari ke-15.

Buah tomat yang disimpan pada hari ke- 15 dengan perlakuan tanpa coating dan perlakuan jenis pati pisang tongka langit menunjukkan peningkatan nilai likopen terbesar masing-masing $53,19 \%$ dan $49,57 \%$. Sementara perlakuan jenis pati sagu dan ubi kayu menunjukkan peningkatan kadar likopen terkecil yaitu masing-masing $23,94 \%$ dan $34,65 \%$.

\section{KESIMPULAN}

1. Buah tomat yang disimpan hingga hari ke-15 tanpa coating secara signifikan mengalami penurunan kekerasan, vitamin $\mathrm{C}$ total asam, dan mengalami kenaikan susut bobot dan likopen.

2. Buah tomat yang di-coating dengan pati sagu tuni, pati ubi kayu, pati pisang tongka langit efektif dalam mempertahankan mutu tomat selama penyimpanan.

\section{DAFTAR PUSTAKA}

Abdi, Y.A., Rostiati, dan S. Kadir. 2017. Mutu fisik, kimia dan organoleptik buah tomat (Lycopersicum esculentum Mill) hasil pelapisan berbagai jenis pati selama penyimpanan. e-Journal Agrotekbis 5: 547555.

AOAC. 1995. Official Methods of Analysis of the Association of Analytical chemists. Washington D.C.

Apandi, M. 1984. Teknologi Buah dan Sayuran. Penerbit Alumni. Bandung.

Breemer, R., P. Picauly, dan N. Hasan. 2017. Pengaruh edible coating berbahan dasar pati sagu tuni (Metroxylon rumphii) terhadap 
mutu buah tomat selama penyimpanan. Agritekno 6: 14-20. DOI: 10.30598/jagritekno.2017.6.1.14

Breemer, R., F.J. Polnaya, dan J Pattipeilohy. 2012. Sifat mekanik dan laju transmisi uap air edible film pati ubi jalar. Seminar Nasional Pangan 2012. 13 November 2012. DOI: $10.13140 / \mathrm{RG} / 2.1 .5154 .0886$

Fitri, A., P.E. Susilowati, dan M. Natsir. 2012. Pektin dari kulit buah kakao (Theobroma cacao L) sebagai edible coating buah tomat. Jurnal Progres Kimia Sains 2: 1-10.

Mu'nisa, A. 2012. Nalisis kadar likopen dan uji aktivitas antioksidan pada tomat asal sulawesi selatan. Jurnal Kajian Penelitian dan Pengajaran Biologi 13: 62-66. DOI: 10.35580/bionature.v13i1.1428

Nawab, A., F. Alam, dan A. Hasnain. 2017. Mango kernel starch as a novel edible coating for enhancing shelf-life of tomato (Solanum lycopersicum) fruit. International Journal of Biological Macromolecules 103: 581-586.

DOI: 10.1016/j.ijbiomac.2017.05.057

Normasari, F. dan B.S. Purwoko. 2002. Pengaruh pemberian $\mathrm{CaCl}_{2}$ prapanen terhadap perubahan kualitas tomat segar selama penyimpanan. Jurnal Buletin Agronomi 30: 53-57.

Pantastico, E.R.B. 1993. Fisiologi Pasca Panen, Penanganan dan Pemanfaatan BuahBuahan dan Sayur-Sayuran Tropika dan Sub Tropika. Gadjah Mada University Press. Yogyakarta.

Polnaya, F.J., J. Talahatu, Haryadi, and D.W. Marseno. 2012. Properties of biodegradable films from hydroxypropyl sago starches. Asian Journal of Food and Agro-Industry 5: 183-192.
Polnaya, F.J., Haryadi, dan D.W. Marseno. 2006. Karakterisasi edible film pati sagu alami dan termodifikasi. Agritech 26: 179-185.

Pranoto, Y., V.M. Salokhe, and S.K. Rakshit. 2005. Physical and antibacterial properties of alginate-based edible film incorporated with garlic oil. Journal of Food Research International 38: 267-272. DOI: 10.1016/j.foodres.2004.04.009.

Rudito. 2005. Perlakuan Komposisi Gelatin dan Asam Sitrat dalam Edible Coating yang Mengandung Gliserol Pada Penyimpanan Tomat. [Skripsi] Program Studi Teknologi Hasil Perkebunan. Politeknik Pertanian Samarinda.

Santoso, B., D. Saputra, dan R. Pambayun. 2004. Kajian teknologi edible coating dari pati dan aplikasinya untuk pengemas primer lempok durian. Jurnal Teknologi dan Industri Pangan 15: 239-244.

Septiana, E. 2009. Formulasi dan aplikasi edible coating berbasis pati sagu dengan penambahan minyak sereh pada paprika (Capsicum annum var Athena). [Skripsi] Fakultas Teknologi Pertanian Institut Pertanian Bogor. Bogor.

Usni, A., T. Karo-Karo, dan E. Yusraini. 2016. Pengaruh edible coating berbasis pati kulit ubi kayu terhadap kualitas dan umur simpan buah jambu biji merah pada suhu kamar. Jurnal Rekayasa Pangan dan Pertanian 4: 293-303.

Wattimena, D., L. Ega, dan F.J. Polnaya. 2016. Karakteristik edible film pati sagu alami dan pati sagu fosfat dengan penambahan gliserol. Agritech 36: 247-252.

Winarno, F.G. dan M.A. Wirakartakusumah. 1981. Fisiologi Lepas Panen. Sastra Hudaya. Jakarta. 